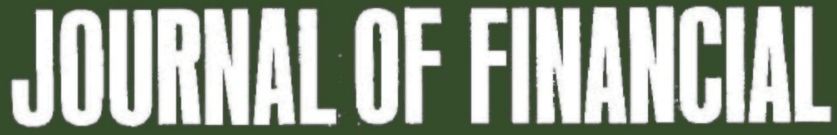

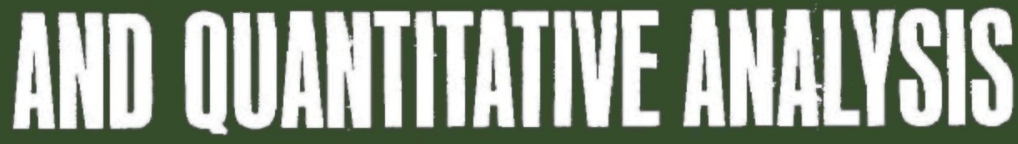

\section{JUNE 1970}

NILS H. HAKANSSON

An Induced Theory of the Firm under

Risk: The Pure Mutual Fund

JAMES GENTRY and JOHN PIKE

An Empirical Study of the Risk-Return Hypothesis Using Common Stock Portfolios of Life Insurance Companies

CHARLES E. EDWARDS and JAMES G. HILTON Some Comments on Short-Run Earnings Fluctuation Bias

JOEL FRIED

Bank Portfolio Selection

GEORGE M. VON FURSTENBERG

Interstate Differences in Mortgage Lending Risks:

An Analysis of the Causes

A. GEOFFREY LOCKETT and CYRIL TOMKINS

The Discount Rate Problem in Cauital Rationing Situations: Comment

PETER LUSZTIG and BERNHARD SCHWAB

The Discount Rate Problem in Capital Rationing Situations: Reply

\section{G. A. WHITMORE}

Diversification and the Reduction of Dispersion: A Note

J. W. COLIN and RICHARD S. BAYER

Calculation of Tax Effective Yields for Discount Instruments 


\section{GRADUATE SCHOOL OF BUSINESS ADMINISTRATION \\ UNIVERSITY OF WASHINGTON \\ SEATTLE, WASHINGTON 98105}

\section{EDITORIAL STAFF}

Charles A. D'Ambrosio, Managing Editor

Charles W. Haley, Associate Managing Editor

Leslye Brueggeman, Editorial Assistant

\section{BOARD OF EDITORS}

Charles A. D'Ambrosio, Washington Fred P. Morrisey, UC, Berkeley

Edward W. Reed, Ist National Bank of Oregon

\section{ASSOCIATE EDITORS}

William W. Alberts, Washington

Marshall E. Blume, Pennsylvania

Charles P. Bonini, Stanford

Richard S. Bower, Dartmouth

William Breen, Purdue

Myles Delano, Michigan State

Thomas R. Dyckman, Cornel1

Robert C. Goshay, UC, Berkeley

Nils H. Hakansson, UC, Berkeley

Robert S. Hamada, Chicago

Frederick S. Hammer

Mark Hanna, Georgia

Austin C. Hoggatt, UC, Berkeley

James R. Jackson, UC, Los Angeles

Frank C. Jen, SUNY Buffalo

Michael C. Jensen, Rochester

Raymond J. Jessen, UC, Los Angeles
Ezra Solomon, Stanford

J. Fred Weston, UCLA

Harry A. Latané North Carolina

James C. T. Mao, British Columbia

John C. McDonald, Stanford

Jacob B. Michaelsen, UC, Santa Cruz

Stewart C. Myers, MIT

Alfred N. Page, Washington

Richard Ro11, Carnegie-Mellon

$R$. Haney Scott, Washington

William F. Sharpe, UC, Irvine

Keith V. Smith, UC, Los Angeles

Roger B. Upson, Minnesota

James Van Horne, Stanford

Paul Wells, Illinois

Richard R. West, Cornell

Robert L. Winkler, Indiana

Donald Woods, UC, Los Angeles

The JOURNAL OF FINANCIAL AND QUANTITATIVE ANALYSIS is published in March, June, September, December, and January, by the Graduate School of Business Administration of the University of Washington in conjunction with the Western Finance Association. The December issue is a special issue devoted to one topic of interest to the JFQA's readership. The January issue contains selected papers, discussants' comments, and Proceedings of the Western Finance Association meetings.

Membership in the Western Finance Association is available at $\$ 7.00$ per year and includes the JOURNAL subscription. Applications and information concerning membership should be addressed to Virginia McKemie-Belt, Western Finance Association, California State College at Long Beach, Long Beach, California 90804 . Make checks payable to the Western Finance Association.

For individuals, the annual subscription rate to the JFQA is $\$ 7.00$; for firms or libraries, the annual rate is $\$ 10.00$. Single copies are $\$ 2.50$, except the special issues, the price of which is $\$ 3.00$. Manuscripts and editorial correspondence should be sent to the Managing Editor. Advertising inquiries and books for review should be addressed to the Associate Managing Editor. 
The views and opinions expressed are those of the authors and do not necessarily reflect those of the Graduate School of Business Administration of the University of Washington or of the Western Finance Association.

(Copyright 1970 by the Graduate School of Business Administration, University of Washington.) 
JOURNAL OF FINANCIAL AND QUANTITATIVE ANALYSIS

Volume V, Number 2, June 1970

An Induced Theory of the Firm Under Risk:

The Pure Mutual Fund . . . . . . . . . . . . . . . 155 Nils H. Hakansson

An Empirical Study of the Risk-Return Hypothes is

Using Common Stock Portfolios of Life Insurance Companies . . . . . . . 179 James Gentry and John Pike

Some Comments on Short-Run Earnings Fluctuation Bias . . . . . . . . 187 Charles E. Edwards and James G. Hilton

Bank Portfolio Selection . . . . . . . . . . . . . . . 203 Joez Fried

Interstate Differences in Mortgage Lending Risks:

An Analysis of the Causes ................... 229 George M. von Furstenberg

\section{COMMUNICATIONS}

The Discount Rate Problem in Capital Rationing

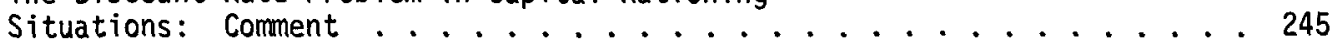

A. Geoffrey Lockett and Cyril Tomkins

The Discount Rate Problem in Capital Rationing

Situations: Reply ................... 261 Peter Lusatig and Bernhard Schwab

Diversification and the Reduction of Dispersion:

A Note ...................... . . 263 G. A. Whitmore

Calculation of Tax Effective Yields for Discount

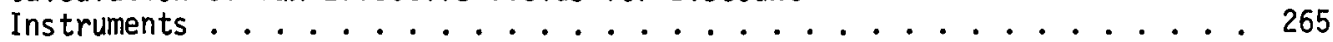
J. W. Colin and Richard J. Bayer

December 1970 Special Issue . . . . . . . . . . . . . . 275

Program of the 1970 WFA Meeting ................ 276 